\title{
BANKING FACILITIES IN TRIBAL DOMINATED RURAL AREAS - \\ A CASE STUDY OF HEZAMARA BLOCK, MOHANPUR, TRIPURA
}

KEY WORDS: Bank Facilities, Financial Inclusion, Tribal Population.

\section{Dr. Sayan Saha*}

Faculty, Maharaja Bir Bikram University, Agartala, Tripura

West, India. *Corresponding Author

\section{Dr. Kiran Sankar Chakraborty}

\author{
Senior Regional Director, IGNOU Agartala, Tripura, India.
}

A bank is a financial institution licensed to receive deposits, make credits and provide other banking facilities transactions, payments and insurance. By the way of implementing the concept of financial inclusion, a vast section of the rural disadvantaged tribal people in India was gradually coming under the ambit of formal banking services. As per the report of the World Bank's (2017) Global Findex shows that nearly 80 percent of the people in India had a bank account. However a significant portion of tribal people in India are excluded from the ambit of the banking facilities in the country. In this background the present paper aims to assess the level of access to banking facilities among the tribal people of Hezamara Block of Mohanpur, Tripura and to study their awareness level about financial products and services offered by the banks. The present study is based on primary data collected from the 200 tribal households in Hezamara Block through a set questionnaire and discussion. It has found that 100 percent of sample tribal respondents are having bank accounts and majority of the respondents have their bank accounts in Tripura Gramin Banks (TGBs) and Tripura State Co-operative Banks (TSCBs) respectively.

\section{INTRODUCTION}

The Government of India and RBI have come up with various schemes to make banking facilities easily accessible to the rural vulnerable section of the society. Because to lead the economic development of a country, the people of that country need to be significantly associated with the banks. As such the availability of banking facilities to the whole section of the society without discrimination must be adopted as one of the key objectives of financial inclusion policy. As per the World Bank's Report (2017) nearly 80 percent of the people in India had a bank account, while a major portion of tribal people is excluded from the ambit of the banking facilities in the country.

Hezamara is a Rural Development Block in the Mohanpur Subdivision of the West Tripura district in Tripura, India. The Block is located between Agartala and Khowai main road via Mohanpur. The populations of the block are mainly tribal. There are twenty villages under the block mostly dominated by tribal population. The main economic activities are agriculture and small businesses, most related to the nearby rubber and tea plantations. As per the Census Report 2011, the total population of Hezamara Block in Mohanpur, West Tripura district is 51,541 . Out of which 17,959 are males while 17,669 are females. In 2011 total of 8,256 families were residing in Hezamara Block. An attempt has been made in the present study to understand the socio-economic status of the tribal beneficiaries of banking facilities, to assess the level of access to banking facilities among the tribal people of Hezamara Block in Mohanpur, Tripura and to examine their awareness level about financial products and services offered by the banks.

\section{REVIEW OF LITERATURE}

Many studies have been conducted on the banking facilities in different regions and times. The extent and nature of banking facilities has analysed from different perspectives. Although different scholars identified level of access to banking facilities and understand the level of awareness of banking products and services is the vital component for enhancing the rural economy. A reasonable attempt has been made to study the literature available within the ambit of the subject related to banking facilities in tribal dominated rural areas.

Marulkar (2010) in "Inclusive Banking: A Strategy towards Inclusive Growth" this paper the author has observed that the banking sector has played an essential role in the development of the nation. While concluding the paper he suggested that inclusive growth can be achieved through an inclusive banking system as the banks have a presence in rural areas and these banks can be used as a tool for enhancing the outreach of banking facilities. Choudhary (2013) in "A detailed study of Micro Finance as a tool for Tribal Transformation in areas of Madhya Pradesh" this paper the author has observed and argued that microfinance has been recognized as a financial tool to tackle the problem of poverty in the financial world and it can manage financial resources of the vulnerable section. This paper argued however that Government attempts alone cannot solve the problem of financial inclusion without the cooperation of the banking sector particularly, in developing countries like India, where the majority of underprivileged people do not have access to any type of banking products and services. The paper has also focused on the aspect that, cooperation among the formal and semi-formal financial sector is to be required to meet the target of 100 percent financial inclusion and further attempts have been required to spread the awareness of micro financing services among the tribal people. Arokiyadass (2013) in "Financial Inclusion: A Bank Led Model among the Scheduled Tribe of Odisha", had enough emphasis has been given to the concept of financial inclusion. The paper has found that the plan of financial inclusion implemented by the Government and the Reserve Bank of India (RBI) through public sector banks has made some notable change in the life style of the scheduled tribe of Odisha. The paper has also suggested that still there are things need to be enhanced in reaching out the unreached and the unbanked people. Annamalai (2014) in his study "Awareness of Financial Inclusion in tribal people in Dharmapuri District" stated that the awareness level of financial inclusion among the tribal community region after its execution, through the plan had a strong social mission of financial inclusion. Finally, the study noted that half of the tribal people are still not getting awareness of banking facilities. Jayakumar and Palaniyammal (2016) in their study, "Socio-Economic Status of Scheduled Tribes in Kalrayan Hills" had shown that a brief overview of the socio economic status of tribes in Tamil Nadu with a special reference to the tribal belonging to the malayali community in kalrayan Hills, Salem district. While concluding the paper they suggested that, at present the Tribal communities are engaged in financial pursuits ranging from hunting to settled agriculture. However, it has been observed that majority of the tribal workers are involved in agricultural pursuit and only 2 percent are involved in non-agricultural pursuits. Borgohain (2016) in her study "Financial Inclusion in 
Assam- An overview" stated that Assam has performed poorly in comparison to India the extent of financial inclusion and the survey data and statistics of banks/other institutions on various dimensions of financial inclusion while expose some significant aspects of the success/failure of financial inclusion drive, when seen individually these fail to give a wholesome picture. Overall, empirical evidence indicates not only limited financial access but also unequal access across households. Boro (2018) in his study "A Study on Financial Inclusion among Tribal People of Chhaygaon Revenue Circle, Kamrup" concludes that financial inclusion is an essential keystone of economic and social development. The paper also stressed upon there is needed to educate and take more steps to make tribal community a part of financial inclusion. The study concludes with if every person of our society takes benefit of the banking facilities than only the society can become economically strong and independent. Shaji and Mathews (2020) in "A Study of the Awareness of Electronic Banking Services among Rural Women of Nelamangala, Bangalore, India" had attempted to analyze the extent to which rural women are aware of e-banking services, and the study is mainly based on the usage of e-banking services offered by banks. This paper has also found that only 15 percent of the rural women respondents have a good understanding of the different kinds of e-banking services and rural women have also required more support and guidance to adapt fully e-banking services offered by banks.

\section{OBJECTIVES OFTHE STUDY}

(1) To understand the socio-economic status of respondents of the study located in Hezamara Block of Mohanpur, Tripura.

(2) To assess the level of access to banking facilities among the tribal people of Hezamara Block, Mohanpur, Tripura.

(3) To examine the awareness level of tribal people about financial products and services offered by the banks in the Hezamara Block of Mohanpur, Tripura.

\section{RESEARCH METHODOLOGY}

The present study was intended to assess the level of access to banking facilities among the tribal vulnerable section of society in Hezamara Block of Mohanpur, Tripura and to study their level of awareness about financial products and services offered by the banks and to understand the difficulties faced by the tribal people in the area of financial inclusion. Five tribal dominated rural villages of Hezamara Block of Mohanpur, Tripura are selected viz. Surendranagar Village, Kamukcherra Village, Purba Chandpur Village, Purba Simna Village and Sonaram Village and 40 respondents from each tribal area were randomly selected for the study. Face to face interview was conducted by using interview schedule to collect information from the respondents. Percentage was used to analyse data on demographic characteristics, level of access to banking facilities and the awareness level of respondents about financial products and services offered by the banks.

\section{SOCIO-ECONOIMIC STATUS OF RESPONDENTS}

The purpose of financial inclusion is delivery of banking services at an affordable cost in a fair and transparent manner to the vulnerable sections of the society.

The table 1 reveals that 91 percent of respondents interviewed in selected survey areas were in the age group of 31 to 60 years. It is observed that 69 percent of the respondents in the survey areas were male. Majority of the respondents were completed only primary and secondary level (83 percent) of education. It is also found that majority of the respondents were working as agricultural labour and cultivator; daily labour (4l percent and 35 percent respectively). It is noted that 31 percent of the respondents were belonging to family monthly income less than `10,000.
Table 1: Socio-Economic Profile of the Respondents

\begin{tabular}{|c|c|c|c|}
\hline \multicolumn{2}{|c|}{ Socio-Economic Factors } & Nos. & $\%$ \\
\hline \multirow[t]{7}{*}{ Age } & Below 20 & 0 & 0 \\
\hline & $21-30$ & 2 & 1 \\
\hline & $31-40$ & 120 & 60 \\
\hline & $41-50$ & 37 & 18 \\
\hline & $51-60$ & 25 & 13 \\
\hline & $61-70$ & 12 & 6 \\
\hline & Above 70 & 4 & 2 \\
\hline \multirow[t]{2}{*}{ Gender } & Male & 137 & 69 \\
\hline & Female & 63 & 31 \\
\hline \multirow[t]{6}{*}{ Education } & Illiterate & 0 & 0 \\
\hline & Primary & 94 & 47 \\
\hline & Secondary & 73 & 36 \\
\hline & Higher Secondary & 5 & 3 \\
\hline & Graduate & 13 & 6 \\
\hline & Post Graduate & 15 & 8 \\
\hline \multirow{5}{*}{$\begin{array}{c}\text { Type of } \\
\text { Occupation }\end{array}$} & Agricultural Labour \& Cultivator & 81 & 41 \\
\hline & Fish Farmer & 9 & 4 \\
\hline & Daily labour & 70 & 35 \\
\hline & Businessmen & 2 & 1 \\
\hline & Employee & 38 & 19 \\
\hline \multirow{6}{*}{$\begin{array}{c}\text { Family } \\
\text { Monthly } \\
\text { Income }\end{array}$} & Less than ` 10000 & 63 & 31 \\
\hline & 10000 - Less than `20000 & 57 & 29 \\
\hline & 20000 - Less than 30000 & 25 & 12 \\
\hline & 30000 - Less than `40000 & 20 & 10 \\
\hline & 40000 - Less than `50000 & 15 & 8 \\
\hline & 50000 and Above & 20 & 10 \\
\hline
\end{tabular}

\section{Source:Field Survey}

\section{Level of Access to Banking Facilities}

The level of access to banking facilities among the tribal people of Hezamara Block, Mohanpur, Tripura is discussed under the following headings.

Table 2: Frequency of having Bank Account

\begin{tabular}{|c|c|c|}
\hline \multirow{2}{*}{ Account } & \multicolumn{2}{|c|}{ Hezamara Block } \\
\cline { 2 - 3 } & Nos. & $\%$ \\
\hline Yes & 200 & 100 \\
\hline No & 0 & 0 \\
\hline Total & 200 & 100 \\
\hline
\end{tabular}

\section{Source:Field Survey}

It is observed that (table 2) out of 200 surveyed respondents 100 percent of respondents are having the bank account.

Table 3: Bank-wise Distribution of Accounts

\begin{tabular}{|c|c|c|}
\hline \multirow{2}{*}{ Accounts in } & \multicolumn{3}{|c|}{ Hezamara Block } \\
\cline { 2 - 3 } & Nos. & $\%$ \\
\hline All Schedule Commercial Banks (ASCB) & 0 & 0 \\
\hline Tripura State Co-operative Banks (TSCB) & 44 & 22 \\
\hline Tripura Gramin Bank (TGB) & 156 & 78 \\
\hline Total & $\mathbf{2 0 0}$ & $\mathbf{1 0 0}$ \\
\hline
\end{tabular}

\section{Source:Field Survey}

From the table 3, it is seen that out of 200 sample respondents 78 percent of the respondents have accounts in Tripura Gramin Banks (TGBs) and 22 percent of the sample households have their bank accounts in Tripura State Cooperative Banks (TSCBs). Thus from the above Table 3 it is revealed that, the maximum number of tribal respondents have their account in TGBs and TSCBs respectively. In the case of financial development in Tripura,TGBs are in the frontline.

Table 4:Type-wise Distribution of Accounts

\begin{tabular}{|c|c|c|}
\hline \multirow{2}{*}{ Types of Account } & \multicolumn{2}{|c|}{ Hezamara Block } \\
\cline { 2 - 3 } & Nos. & $\%$ \\
\hline SB Account & 194 & 97 \\
\hline
\end{tabular}
|www.worldwidejournals.com $\mid$ 


\begin{tabular}{|c|c|c|}
\hline GCC Account & 0 & 0 \\
\hline No-Frill Account & 2 & 1 \\
\hline Other Accounts (SCC, KCC \& SHGs) & 4 & 2 \\
\hline Total & $\mathbf{2 0 0}$ & $\mathbf{1 0 0}$ \\
\hline
\end{tabular}

\section{Source:Field Survey}

From the table 4 , it is found that out of 200 tribal respondents the majority 97 percent of the sample respondents have the account in Savings Bank (SB) accounts, while only l percent of the respondents have the No-Frill accounts and then 2 percent of the respondents had the other group of accounts such as Swarojgar Credit Card (SCC), Kisan Credit Card (KCC) and Self-help Groups (SHGs), whereas no respondents have GCC account. From the above Table 4 it is known that among the sample respondents most of the selected respondents have savings account.

\section{Table 5: Access to Banking Facilities}

\begin{tabular}{|c|c|c|c|}
\hline \multicolumn{2}{|c|}{ Access to Banking Facilities } & Nos. & $\%$ \\
\hline Having BCs & Yes & 85 & 43 \\
\cline { 2 - 4 } & No & 115 & 57 \\
\cline { 2 - 4 } & Total & $\mathbf{2 0 0}$ & $\mathbf{1 0 0}$ \\
\hline \multirow{4}{*}{ Have Debit Card } & Yes & 173 & 86 \\
\cline { 2 - 4 } & No & 27 & 14 \\
\cline { 2 - 4 } & Total & $\mathbf{2 0 0}$ & $\mathbf{1 0 0}$ \\
\hline \multirow{4}{*}{ Credit Services } & Yes & 20 & 10 \\
\cline { 2 - 4 } & No & 180 & 90 \\
\cline { 2 - 4 } & Total & $\mathbf{2 0 0}$ & $\mathbf{1 0 0}$ \\
\hline
\end{tabular}

\section{Source:Field Survey}

It is observed from table 5 that 43 percent of the tribal respondents have Business Correspondents (BCs) facility. The table also exhibits that 86 percent of sample have debit cards, while 14 percent don't have debit cards for access to ATM facility. Majority (90 percent) of the respondents are not able to get credit services from banks. Now, the picture is same in all the sample villages of Hezamara Block of Mohanpur, Tripura. Based on the results of the respondents, it can be verified that in almost every villagers of the state are availed maximum banking services by the medium of $\mathrm{BCs}$ and they do not get credit facilities from banks as per their requirement.

Table 6: Sources for Availing of Loans

\begin{tabular}{|c|c|c|}
\hline \multirow{2}{*}{ Sources of Loans } & \multicolumn{2}{|c|}{ Hezamara Block } \\
\cline { 2 - 3 } & Nos. & $\%$ \\
\hline Formal Credit (Banks) & 29 & 14 \\
\hline Micro Credit & 70 & 35 \\
\hline SHGs \& Co-operatives & 101 & 51 \\
\hline Friends & 0 & 0 \\
\hline Family/ Relatives & 0 & 0 \\
\hline Money Lenders & 0 & 0 \\
\hline Total & $\mathbf{2 0 0}$ & $\mathbf{1 0 0}$ \\
\hline
\end{tabular}

\section{Source:Field Survey}

Table 6, indicates that the sources for availing loans of sample respondents in the five villages of Hezamara Block of Mohanpur, Tripura. Out of 200 tribal respondents, majority 51 percent have availing their loans from Self-Help Groups (SHGs) and Co-operatives. Whereas 35 percent of respondents have availing of loans from micro credits and only 14 percent of the sample respondents have formal credit facilities from Banks. It is found that none of the respondents of these sample villages took loans from friends, family members and money lenders for their needs.

Table 7: Debit Card Holder are Assisted by Using ATMs

\begin{tabular}{|c|c|c|}
\hline \multirow{2}{*}{ Assisted by } & \multicolumn{2}{|c|}{ Hezamara Block } \\
\cline { 2 - 3 } & Nos. & $\%$ \\
\hline Self & 38 & 19 \\
\hline Family Members & 160 & 80 \\
\hline Friends & 2 & 1 \\
\hline
\end{tabular}

www.worldwidejournals.com |

\begin{tabular}{|c|c|c|}
\hline Bank Staffs & 0 & 0 \\
\hline Total & 200 & 100 \\
\hline
\end{tabular}

\section{Source:Field Survey}

Table 7 emphasized that, out of 200 bank account holders the majority (81 percent) of the debit card holders are getting help from family members and friends, 19 percent of the tribal respondents are using ATMs services by self. It is also observed that not a single respondent of the sample villages doesn't want any kind of help from bank staff for using debit cards.

Table 8:Visit-Frequency for Operating Accounts

\begin{tabular}{|c|c|c|}
\hline \multirow{2}{*}{ Frequency of Operating Accounts } & \multicolumn{2}{|c|}{ Hezamara Block } \\
\cline { 2 - 3 } & Nos. & $\%$ \\
\hline Weekly & 0 & 0 \\
\hline Monthly & 41 & 21 \\
\hline Every Two Months & 117 & 58 \\
\hline Every Three Months & 35 & 17 \\
\hline Every Six Months & 7 & 4 \\
\hline Total & $\mathbf{2 0 0}$ & $\mathbf{1 0 0}$ \\
\hline
\end{tabular}

\section{Source:Field Survey}

From table 8 , it is observed that, only 4 percent of the respondents have operate debit cards once in every six months, 17 percent and 21 percent respondents are operating their debit cards once in every three months and once in a month respectively. It is also found that majority 58 percent of tribal respondents have operated debit cards once in every two months for deposits and withdrawals in Tripura. From this discussion we can conclude that tendency of accountholders to reach the banks are equal in all the villages of Hezamara Block of Mohanpur in Tripura. The results prove that the people visit to banks in every two to three months for withdraw the payment which they get through MGNREGA, pensions, students stipend and other financial assistance.

Table 9:Types of uses of Services by Bank and Bcs

\begin{tabular}{|c|c|c|}
\hline \multirow{2}{*}{ Types of Services } & \multicolumn{2}{|c|}{ Hezamara Block } \\
\cline { 2 - 3 } & Nos. & \% \\
\hline Small Value of Deposits & 16 & 8 \\
\hline Limited Withdrawals & 47 & 24 \\
\hline Pensions & 20 & 10 \\
\hline Small value of SHG Linkage & 71 & 36 \\
\hline Small Value of Remittances & 46 & 22 \\
\hline Total & $\mathbf{2 0 0}$ & $\mathbf{1 0 0}$ \\
\hline
\end{tabular}

Source:Field Survey

On behalf of a correspondent bank, a Business Correspondents (BCs) can disburse and recover small value loans; collect small value deposits, receive and send small value remittances; cross-sell third party products such as pension products, micro insurance, and engaged in bill payments for services. The Table 9 showed that, out of 200 bank account holders the maximum (36 percent) of accountholders are getting services of small value SHG linkage, 24 percent tribal respondents are getting limited withdrawals and 22 percent are getting services of small value remittances. It is also found that only 10 percent and 8 percent of the tribal respondents are getting the financial services of pensions and small value deposits from the Banks and $\mathrm{BCs}$ respectively.

\section{Awareness Level about Financial Products and Services Offered by Banks}

From the table 10, it is found that out of 200 sample tribal respondents 12 percent of the respondents are unaware about formal banking products and services, 17 percent of respondents have poorly awareness and 51 percent of the tribal respondents have fairly aware on banking products and services. Whereas, only 15 percent and 7 percent of the respondents are moderately aware and extremely aware respectively. In almost all the tribal dominated villages of 
Hezamara Block of Mohanpur in Tripura the maximum numbers of respondents were fairly aware about the banking products and financial services. It is clear that, 67 percent of the tribal respondents are poorly aware and only 12 percent are extremely aware on banking service charges in the five selected villages of Hezamara Block of Mohanpur in West Tripura. From the above analysis it can be observed that most of the tribal respondents in the present study area are unaware as well as poorly aware about the banking service charges. The table 10 shows that, out of 200 selected tribal respondents, the majority ( 84 percent) are unable to use Internet banking and the level of extremely awareness is 5 percent, while only the least 3 percent of are fairly aware and 6 percent of the sample respondents are poorly aware on Internet banking. Table 10 also presents the overall scenario of level of awareness on mobile banking among the tribal respondents in five sample villages of Hezamara Block in West Tripura District. The majorities (86 percent) of the respondents are unaware on mobile banking, 6 percent are poorly aware and the level of extremely awareness on mobile banking is only 1 percent. While the level of fairly awareness is also 6 percent in the selected four districts of Tripura. From the above mentioned discussion it is clear that most of the respondents are not aware of mobile banking facilities. From the Table 10 result can be drawn that only 12 percent of the sample respondents can use mobile banking tools but whatever they know are not sufficient. It is found that the majority ( 66 percent) of the tribal respondents are fairly aware on debit card facilities, while the percent of level of moderately awareness and extremely awareness are only 12 and 8 respectively. The table 10 also showed the overall scenario of awareness on credit cards facility. The majority (72 percent) of the 200 sample tribal respondents are unaware on credit card facilities, 17 percent are poorly aware. Whereas, only 1 percent and 4 percent of the respondents are aware on facilities of credit card at extreme level as well as moderate level in the five tribal dominated sample villages. It is found that the essential requirements of loans of tribal respondents in the five sample villages, out of 200 tribal respondents only 3 percent have extreme level of aware, 7 percent have moderately aware and 17 percent of the respondents have fair awareness regarding the essential requirements of banking loans (provision for mortgage).

Figure 1: Average Level of Awareness about Banking Facilities

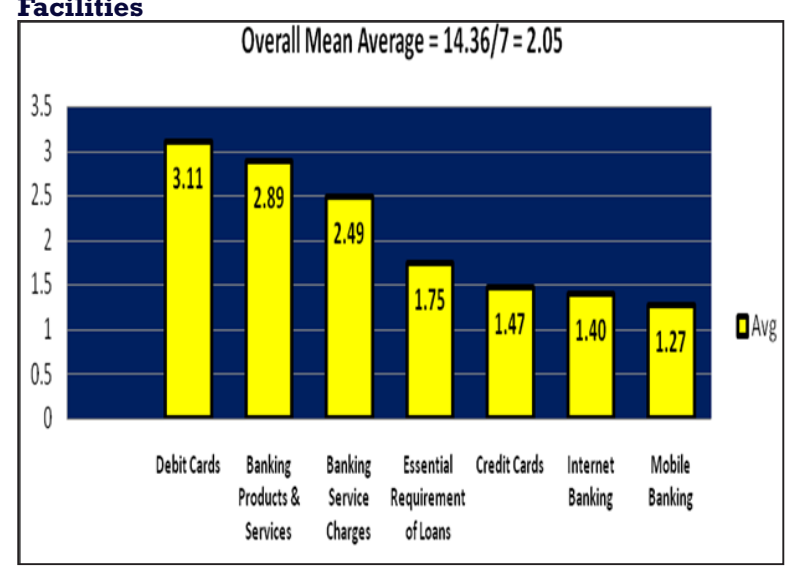

\section{Source: Field Survey}

From the above table 10 and figure 1, the awareness level of tribal respondents based on seven banking services. By taking the average level of awareness of each banking services, I can rank the awareness level. In this table and figure, it is observed that awareness level of banking services 'debit cards' occupies the first rank among other financial services offered by banks, because it has the highest average, i.e., 3.11. The second position is gained by the financial services indicator 'banking products and services'. It has an average of 2.89. Banking services 'mobile banking' has the lowest level of awareness as it occupies the last ranks, among other banking services. In the case of awareness level of tribal people of Hezamara Block, their overall mean average is 2.05, which lies between 2 and 3, so I can say that poorly aware of banking services have only average level of awareness. Where, TS = Total Sum, TF = Total Frequency, Avg. = Average.

\begin{tabular}{|c|c|c|c|c|c|c|c|c|c|c|c|c|c|c|c|}
\hline & ole 10: Awareness & $\mathbf{I}$ & f $\mathbf{F}$ & & & & Fina & $\pi$ & 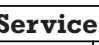 & 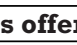 & l by & 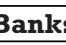 & & & \\
\hline No. & Awareness about & Una & ware & & $\begin{array}{l}\text { orly } \\
\text { are }\end{array}$ & & $\begin{array}{l}\text { irly } \\
\text { vare }\end{array}$ & Mo & $\begin{array}{l}\text { erately } \\
\text { vare }\end{array}$ & $\begin{array}{r}\text { Extre } \\
\text { Aw }\end{array}$ & $\begin{array}{l}\text { rely } \\
\text { re }\end{array}$ & Ts & $\mathbf{T F}$ & Avg. & Rank \\
\hline & & $\mathbf{F}$ & $\mathbf{S}$ & $\mathbf{F}$ & $\mathbf{S}$ & $\mathbf{F}$ & $\mathbf{S}$ & $\mathbf{F}$ & $\mathbf{S}$ & $\mathbf{F}$ & $\mathbf{S}$ & & & & \\
\hline 1 & Banking Products \& Services & 23 & 23 & 33 & 66 & 101 & 303 & 30 & 120 & 13 & 65 & 577 & 200 & 2.89 & 2 \\
\hline 2 & Banking Service Charges & 15 & 15 & 133 & 266 & 14 & 42 & 15 & 60 & 23 & 115 & 498 & 200 & 2.49 & 3 \\
\hline 3 & Internet Banking & 167 & 167 & 12 & 24 & 6 & 18 & 5 & 20 & 10 & 50 & 279 & 200 & 1.40 & 6 \\
\hline 4 & Mobile Banking & 171 & 171 & 12 & 24 & 12 & 36 & 3 & 12 & 2 & 10 & 253 & 200 & 1.27 & 7 \\
\hline 5 & Debit Cards & 5 & 5 & 24 & 48 & 132 & 396 & 23 & 92 & 16 & 80 & 621 & 200 & 3.11 & 1 \\
\hline 6 & Credit Cards & 143 & 143 & 33 & 66 & 14 & 42 & 8 & 32 & 2 & 10 & 293 & 200 & 1.47 & 5 \\
\hline 7 & Essential Requirement of Loans & 129 & 129 & 18 & 36 & 33 & 99 & 14 & 56 & 6 & 30 & 350 & 200 & 1.75 & 4 \\
\hline
\end{tabular}

[Unaware (1), Poorly Aware (2), Fairly Aware (3), Moderately Aware (4), Extremely Aware (5)]

Source:Field Survey

\section{CONCLUSION}

Using the primary data collected from 200 sample beneficiaries of financial inclusion belonging to rural areas across the five villages of Hezamara Block in West Tripura district. In this paper an attempt has been made to elicit the responses of tribal bank beneficiaries with regard to access to banking facilities for measuring the level of awareness about financial products and services offered by the banks in the tribal vulnerable section of the society in Hezamara Block of Mohanpur, Tripura. The analysis is based on primary sources of data collection i.e. survey. In depth interviews of respondents and pilot survey's response became the base of structured questionnaire and finally the 200 common beneficiaries were included and analysed. The subjects of the study have expressed their discontent as regards the socioeconomic status of the respondents of financial inclusion. Thus the socio-economic status have been perceived by analysing the parameters namely age, gender, level of literacy, occupation and monthly income of the respondents. However, respondents have shown their views regarding the access of banking facilities with regard to frequency of having bank accounts, bank-wise distribution of accounts, type-wise distribution of accounts, access to banking products and services, level of access to credit services, sources for availing of loans, debit card holder for accessing to ATM facility, bank-visit frequency for operating accounts, types of uses of services by Banks and BCs and to study the awareness level of sample respondents about financial products and services offered by the Banks.

\section{REFERENCES:}

[1] Annamalai, C. (2014) "Awareness of Financial Inclusion on tribal people in Dharmapuri District"'ISSN: 2320-5504, E-2347-4793,Vol-1 Issue-XVIII.

[2] Arivazhagan, P. (2019). A Study on Banking Habits of People in Urban and Rural Area.A Journal of Composition Theory, XII (IX), 1451-59.

[3] Arokiyadass, V. (2013). Financial Inclusion: A Bank Led Model Among The Scheduled Tribe of Odisha. International Journal of Advanced Research in Management and Social Sciences, 2 (10), 42-53.

[4] Balaji, R. (2014). Financial Inclusion among Tribals in Nilgiris District. Journal of Radix International Educational and Research Consortium, 3 (6), 1-13.

[5] Borgohain, N. (2016). Financial Inclusion in Assam-An Overview. Research J. Humanities and Social Sciences, 7 (2), 11 1-120. [6] Boro, J. K. (2018). A Study on Financial Inclusion among Triabl People of 
Chhaygaon Revenue Circle, Kamrup. A Peer-Reviewed International Journal of Humanities \& Social Science, VI (IV), 281-288.

[7] Census of India, (2011). District Census Handbook West Tripura District. Agartala:Directorate of Census Operations,Tripura.

[8] Choudhary, M. (2013). A detailed study of Micro Finance as a tool for Tribal Transformation in areas of Madhya Pradesh. International Journal of Business and Management Invention, 2 (3), $72-76$.

[9] Dangi, N. \& Kumar, P. (2013). Current Situation of Financial Inclusion in India and Its Future Visions, International Journal of Management and Social Sciences Research (IJMSSR), Vol.2, No.8.

[10] Debbarma, S. (2019). A Study on The Socio-Economic Status of Rural Handicraft Artisans in Hezamara R.D Block, West Tripura District, Tripura. Centre For Rural Development. Tamil Nadu: Centre For Rural Development, Annamalai University.

[11] Demirgüç-Kunt, A., Klapper, L., Singer, D., Ansar, S., \& Hess, J. (2017). The Global Findex Database- Measuring Financial Inclusion and the Fintech Revolution. World Bank Group.

[12] Jayakumar, A., \& Palaniyammal,P. (2016). Socio-Economic Satus of Scheduled Tribes in Kalrayan Hills. International Journal of Research - GRANTHAALAYAH, $4(3), 22-30$.

[13] Karanth, B. (2018). Banking Habits Among Beedi Workers: Gaps and Opportunities for Financial Inclusion. Research Gate, (pp. 1-12).

[14] Kumar, B. P. (2017, July 17). Financial Vulnerability among Tribes in Rural Areas: Certain Observations from a Study. Munich Personal RePEc Archive , 110.

[15] Marulkar, K. V. (2010). Inclusive Banking : A Strategy Towards Inclusive Growth. International Conference on Quantitative Methods in Money, Banking and Finance, 1-13.

[16] Rajeev, M. (2015). Financial Inclusion and Disparity: A Case of India. Global Labour UniversityWorking Paper, 37, 1-31.

[17] Sa-Dhan. (2010). Policy Interface 2010: A Report- Interface on Financial Inclusion of Dalits, Tribals and Religious Minorities: Issues, Challenges and Way Forward. New Delhi:United Nations Development Programme.

[18] Sahoo, A. K., Pradhan, B. B., \& Sahu, N. C. (2017). Determinants of Financial Inclusion in Tribal Districts of Odisha: An Empirical Investigation. SAGE Publications, 47 (1), 45-64.

[19] Sarkar, S.S. (2013). A Study on Financial Inlcusion in Urban Areas of Assam, Tezpur University, Thesis, pp. 1-211.

[20] Shaji, A. K., \& Mathews, A. P. (2020). A Study of the Awareness of Electronic Banking Services among Rural Women of Nelamangala, Bangalore, India. Journal of InternationalWomen's Studies, 21 (5), 88-96.

[21] SUBEESH, V. K. (2018). An Evaluation of Financial Inclusion Activities of Banks In Kerala"-With Special Focus on Malabar Area. Minor Research Project Report, SARBTM Govt. College, Koyilandy, Kozhikode.

[22] Tiwari, P. (2014). Financial Inclusion of Tribal Women: Role of Upcoming Women's Banks. International Journal of Science and Research (IJSR), 3 (7), 4-5.

[23] Govt. of Tripura, (2019-20). Economic Review of Tripura. Agartala:Directorate of Economics \& Statistics Planning (Statistics).

[24] Kumar,V.V.A. (2013). A Study on the Role of District Co-operative Banks in the Financial Inlcusion in Kerala. Thesis, pp. 1-481.

[25] Census 2011 Data (https://censusindia.gov.in/pca/pcadata/pca.html) censusindia.gov.in

[26] Hezamara, Tripura (https:// en. wikipedia. org/ wiki/ Special: Search? search=Hezamara $\% 2 C W e s t+$ Tripura\&ns $0=1$ ) -Wikipedia 